\title{
Molecular and Symbiotic Efficiency Characterization of Rhizobia Nodulating Bambara Groundnut (Vigna subterranea L.) from Agricultural Soils of Daloa Localities in Côte D'ivoire
}

\author{
Guei Nassé Kaéda Raissa ${ }^{1}$, Konate Ibrahim ${ }^{1 *}$, Taha Kaoutar ${ }^{2}$, Bamba Issouf ${ }^{1}$, \\ Beugre Grah Avit Maxwell ${ }^{1}$, Akaffou Doffou Sélastique ${ }^{1}$ and Filali-Maltouf Abdelkarim² \\ ${ }^{1}$ UFR Agro-forestry and Environment, Department of Biochemistry and Microbiology, \\ Laboratory of Agrovalorization, Jean Lorougnon Guede University, \\ B.P: 150 Daloa, Côte d'Ivoire \\ ${ }^{2}$ Laboratory of Microbiology and Molecular Biology, Faculty of Sciences, \\ University Mohammed V in Rabat, Morocco \\ *Corresponding author
}

\author{
A B S T R A C T
}

\begin{tabular}{|c|}
\hline Keywords \\
\hline $\begin{array}{l}\text { Bambara } \\
\text { groundnut, } \\
\text { Rhizobia, symbiotic } \\
\text { efficiency, 16S- } \\
\text { rRNA, phylogeny }\end{array}$ \\
\hline Article Info \\
\hline $\begin{array}{l}\text { Accepted: } \\
\text { 05 June } 2020 \\
\text { Available Online: } \\
10 \text { July } 2020\end{array}$ \\
\hline
\end{tabular}

\begin{abstract}
Bambara groundnut (Vigna subterranea L. Verdc.) is an indigenous, drought-tolerant, underutilized African food legume, with the ability to fix atmospheric $\mathrm{N}_{2}$ in symbiosis with soil rhizobial bacteria. Our work aimed to analyze the genetic diversity of 15 bacteria isolated from root nodules of Bambara groundnut coded RVC in Côte d'Ivoire and to evaluate their symbiotic characteristic in order to select the most efficient strains as biofertilizers. Molecular analysis of these isolates using 16S rRNA gene sequences revealed distinct evolutionary lineages related to the genus Rhizobium (80\%), Bradyrhizobium (13.3\%) and Ensifer (6.7\%). Specifically, these isolates were very closed to B. yuanmingense, Rhizobium sp. A2Ec4, Rhizobium sp. HIN2, R. alamii CK-8, R. sullae SCAU26, Rhizobium sp. UFLA 02-232, Rhizobium sp.UFPI-38 and Ensifer sp. PZS-S05. The nodulation test showed significant differences $(\mathrm{P}<0.05)$ in nodule number (18 and 87/plant) and dry matter $(21.67$ and $289.33 \mathrm{mg} / \mathrm{plant}$ ). Besides, the isolates RVC25, RVC50, and RVC13 exhibited the highest infectious capacity with a means of symbiotic effectiveness ranged from 42 to $83 \%$. The isolate RVC25 was scored as highly effective (83\%). Thus the strain RVC25 characterized as $R$. alamii was identified as having interesting symbiotic features to improve the Bambara groundnut production. Symbiotic parameters had a significant contribution to growth, health and yield of the host plant.
\end{abstract}

\section{Introduction}

Rhizobia are soil bacteria belonging to the groups of $\alpha, \beta$ and $\delta$ Proteobacteria (Chen et al., 2003; Garrity et al., 2003; Benhizia et al., 2004). They are truly characterized by their capacity to form nodules on the roots and sometimes the stems of host plants generally legumes and to grow on the isolation YEM medium (Vincent, 1970). Inside the nodule and in the bacteroids form and via the nitrogenase enzyme activity, they fix and reduce atmospheric nitrogen $\left(\mathrm{N}_{2}\right)$ to ammonia $\left(\mathrm{NH}_{3}\right)$ exploitable by the host plant (Dixon and Wheeler, 1986; Graham, 2008). Thus, these symbionts are widely used in the 
agricultural and forestry system as biofertilizer and bio-re-mediator agents (Sayeda et al., 2005). Their uses and benefits are well known in several regions of the world, especially in America (Torres-Júnior et al., 2014), Europe (Rincón et al., 2008), Asia (Ren et al., 2011), Australia (Sessitsch et al., 2002), North Africa (Maâtallaha et al., 2002) and South Africa (Hassen et al., 2014).

With the exception of Senegal (Sylla et al., 2002) which is very advanced in this area, these beneficial bacteria are less known in West Africa and rarely applied as inoculums to improve the productivity of leguminous plants and the fertility of soils deficient in mineral nutrients. To develop this research theme in Côte d'Ivoire, we have started some investigations at the Jean Lorougnon Guédé University (UJLoG) in order to contribute to enhancing the native Rhizobia with local food legumes marginalized such as Bambara groundnut (Vinga subterranea L). So, we aim in this work to (i) consolidate our preliminary results (Geui et al., 2019) by expanding our collection and confirming the symbiotic efficacy of the isolates and to (ii) identify by molecular method these Rhizobia nodulant Vigna s. in the localities of Daloa.

\section{Materials and Methods}

The isolation and authentication of the bacteria nodulating Vinga subterranea L. were conducted in vitro at the Jean Lorougnon Guédé University in Côte d'Ivoire. The symbiotic efficiency and genetic diversity tests of these isolates were carried out in the greenhouse and in vitro at the Faculty of Science of Mohammed V, Rabat, Morocco.

\section{Sampling site}

Soil samples were taken at five sites comprising Bribouo, Toroguhé, Jean Lorougnon Guedé University, Zakoua and
Zépréguhé in the localities of Daloa in Côte d'Ivoire.

\section{Isolation of bacterial strain from nodules}

To enlarge our collection, five varieties of $V$. subterranea L. seeds (Figure 1) were used to trap the rhizobia in the different samples of the collected soil. The isolation and purification of native Rhizobia were conducted according to the method described by Maâtallaha et al., (2002) and Geui et al., (2019).

\section{Bacterial DNA isolation}

The total DNA of the 15 authenticated Vigna bacteria was obtained by extraction with Phenol-chloroform and with RNase treatment, from pure the cultures in phase of exponential growth in YEM medium. The isolation of pure DNA has carried out according to the Chen and Tsong-teh (1993) method in a volume of $300 \mu \mathrm{L}$ of bacterial lysis buffer: (40 mM Tris acetate ( $\mathrm{pH} 7.8$ ), $1 \mathrm{mM}$ EDTA, $1 \%$ SDS, $20 \mathrm{mM}$ sodium acetate and RNase at $20 \mathrm{mg} / \mathrm{ml}$ ) and $100 \mu \mathrm{L}$ of $5 \mathrm{M} \mathrm{NaCl}$. After purification with the Phenol-Chloroform mixture $(\mathrm{v} / \mathrm{v})$, the pellet resulting from centrifugation was successively washed with $100 \%$ and $70 \%$ ethanol, then suspended in 55 $\mu \mathrm{L}$ of TE ( $\mathrm{pH} 7.8,10 \mathrm{mM}$ Tris, 1 mM EDTA) and stored at $-20^{\circ} \mathrm{C}$. The quantity and quality of the DNA extract were evaluated using the Nanodrop $^{\mathrm{TM}}$ Spectophotometer at an absorbance of $260 \mathrm{~nm}$ (DNA) and $280 \mathrm{~nm}$ (Protein). The PCR amplification reactions were carried out using $20 \mathrm{ng}$ of pure DNA from each bacterial isolate.

PCR amplification of the 16S-rRNA gene and sequencing

A universal primer pair, fD1 (5'AGAGTTTGATCCTGGCTCAG-3') and rD1 (5’AAGGAGGTG ATC CAG CC-3') 
(Weisburg et al., 1991) was used to amplify the 16S rRNA gene. The final volume of the PCR reaction mixture was $25 \mu \mathrm{L}$ containing $12.5 \mu \mathrm{L}(2 \mathrm{X})$ of myTaq Mix (BIOLINE), 1 $\mu \mathrm{L}$ each pair of primers, $1 \mu \mathrm{L}(20 \mathrm{ng})$ of DNA extract and $9.5 \mu \mathrm{L}$ of PCR water without nuclease. The reaction mixture was incubated in a PCR thermocycler (multiGeneoptiMAX, Labnet) under the following temperature profile: initial denaturation at $95^{\circ} \mathrm{C}$ for $3 \mathrm{~min}$, 35 cycles of denaturation at $94{ }^{\circ} \mathrm{C}$ for $1 \mathrm{~min}$, annealing at $54^{\circ} \mathrm{C}$ for $45 \mathrm{~s}$ and extension at 72 ${ }^{\circ} \mathrm{C}$ for 2 min. $5 \mu \mathrm{L}$ of each PCR product was analyzed by electrophoresis on agarose gel $(1 \% \mathrm{w} / \mathrm{v})$ and migrated for $90 \mathrm{~min}$ at 70 volts. The visualization of the band was carried out with BET $(10 \mathrm{mg} / \mathrm{mL})$ under ultraviolet light using the ENDURO ${ }^{\mathrm{TM}}$ GDS.

\section{Sequences alignment and phylogenetic analyses}

The quality of the $16 \mathrm{~S}$ gene sequences of each 15 bacterial isolate was verified using Chromas LITE version 2.1. The alignment of all the sequences was obtained using Unipro Ugene version 33 and corrected manually with geneDOC version 2.7 (Normand et al., 1996). The most similar sequence for each different haplotype was searched in the GenBank database using the BLASTN program (Altschul et al., 1990).

Including a representative of each haplotype detected in the previous analyses, we reconstructed either single gene or concatenated sequences phylogenies. A maximum likelihood (ML) approach using software MEGA version 6 (Tamura et al., 2013), including the choice of the best model of molecular evolution (following the Akaike information criterion) implemented in MEGA, was applied. The Bootstrap support for each node tested with 1000 replicas was used to cluster the associated taxa and replicate.

\section{Symbiotic efficiency characteristic}

\section{Confirmation of isolated rhizobia through nodulation test}

Inoculation tests on sterile sand confirmed the nodulation capacity of the bacteria isolated from the Bambara groundnut. The 15 preselected isolates were subjected to this test applying the method of Amani et al., (2019). Three replicate pots with seedlings inoculated by $1 \mathrm{~mL}$ of broth culture of each isolate were then transported to the glasshouse and left to grow under natural conditions. Three pots with $\mathrm{N}$-free uninoculated plants served as a negative control, while $5 \mathrm{mM}$ nitrate-fed plants served as a positive control.

\section{Morpho-agronomic characteristic of inoculated plants}

Thirty-seven days after inoculation, the plants were uprooted to assess the effect of local rhizobia on the following agronomic parameters of Vigna: the lengths of the stem and roots, the fresh and dry weight of the aerial and root parts, the color of the leaves and roots (plant vitality and health).

\section{Characterization of the symbiotic efficiency of bambara groundnut rhizobia}

The evaluation of the symbiosis parameters was carried out by taking the following data: the number of nodules, the dry matter of the nodules, the dry matter of the roots and the dry matter of the aerial parts. Drying is carried out in an oven at $65^{\circ} \mathrm{C}$ for 72 hours.

The exploitation of the number and dry weight of the nodules made it possible to assess the infectivity and the air yield in dry matter to calculate the relative symbiotic efficiency (SEi) by comparing the biomass of each plant inoculated with the biomass of control plants fed with nitrogen. 
The relative symbiotic efficiency was estimated according to the method of Chibeba et al., (2018):

$\mathrm{SEi}=(\mathrm{x} / \mathrm{y}) * 100$

$\mathrm{x}=$ dry matter of inoculated plants; $\mathrm{y}=$ dry matter of plants supplied with $5 \mathrm{mM} \mathrm{KNO}_{3}$.

The symbiotic efficiency was expressed in Relative index (IR) according to the mathematical formula of Cheriet (2016) comparing the dry biomass the aerial part of the plants inoculated with the controls without nitrogen:

$\mathrm{RI}=\mathrm{a} / \mathrm{b}$

$\mathrm{a}=$ dry matter of the inoculated plants and $\mathrm{y}=$ dry matter of plants control

\section{Statistical analysis}

The data obtained were analyzed using $\mathrm{R}$ version 3.5.1 software (R Core Team, 2018) and reported as means of three replicates. One-way analysis of variance and StudentNewman-Keuls test were used to compare the number and dry matter of nodules, shoot dry matter and root dry matter of inoculated plant with rhizobia isolated from Bambara groudnut plants grown on different soils. Differences with $\mathrm{P}<0.05$ were considered significant.

\section{Results and Discussion}

\section{isolation of bacteria from bambara groundnut}

A total of 15 bacteria were isolated from Bambara groundnut (Vigna subterranea L.) root nodules grown on five different soil samples. No bacteria were observed on the YEM medium inoculated with the water used in the final rinsing of the surface of the nodule. The isolates morphologically resemble rhizobia and differ from each other in terms of appearance, shape, diameter and color of the colony. However, they form gummy colonies on the solid YM medium at $28^{\circ} \mathrm{C}$. These isolates are fast-growing with a diameter of the colonies varying between 2 and $7 \mathrm{~mm}$ after 2 to 3 days of culture (Figure 2).

\section{Phylogenetic analysis of the 16S-rRNA gene}

The amplification via PCR of the genomic region of $16 \mathrm{~S}$ rRNA of these 15 bacteria isolated from the $V$. subterranea $\mathrm{L}$. nodules generated, on Agarose gel, a single DNA band of approximately $1500 \mathrm{bp}$. The sequencing of this band and the computer analysis of its data revealed genetic diversity among these native isolates. Identified, they are mainly composed of the genus Rhizobium (80\%) followed by Bradyrhizobium (13.3\%) then weakly by Ensifer (6.7\%).

The phylogenetic tree representing different species of rhizobial reference strains including local isolates was built by the neighborhood (NJ). These local isolates were distinctly divided into six clusters (Fig. 3). Cluster I contains 2 reference strains and shows a genetic link between the 2 local isolates RVC45 and RVC11 with the species Bradyrhizobium yuanmingense and 3 isolates RVC50, RVC13 and RVC23 with the species Rhizobium sp A2Ec4.

Cluster II showed an intimate genetic relationship between the isolate RVC33 to the species Rhizobium sp. HIN2. Cluster III contains 2 groups of local isolates (a) RVC38 and RVC9 and (b) RVC47 and RVC34 well linked respectively to the Rhizobium sallue and Rhizobium sp UFLA species. In cluster IV, the local isolates RVC28, RVC6 and RVC12 were relatively linked to the species 
Rhizobium sp UFPI. At the end, clusters V and VI separately contain the isolates RVC25 and RVC15 which have $100 \%$ similarity respectively with the species Rhizobium alamii $\mathrm{CK}$ and the species Ensifer sp PZS.

\section{Symbiotic efficiency characteristic}

\section{Morpho-agronomic characteristic of inoculated plants}

This study revealed, in general, a correlation between the morpho-agronomic parameters evaluated and a significant difference $(\mathrm{P}<0.05)$ between inoculated plants, noninoculated plants (without $\mathrm{N}$ ) and plants fed with N. In fact, the inoculated plants mainly formed light brown roots compared to the dark brown roots of plants fed with $\mathrm{N}$ and the whitish roots of control plants without N (Fig. 4).

For the color of the leaves, the plants supplemented with $\mathrm{N}$ as well as those inoculated showed dark green leaves except the isolates RVC12, RVC15, RVC23, and RVC47 which produced light green leaves different from greenish colors induced by the non-inoculated control plants (Table 1). Plant vitality was positively correlated with leaf color. Inoculated plants and positive control plants $(+\mathrm{N})$ were more vigorous compared to negative control plants $(-\mathrm{N})$.

In contrary with morphological parameters related to the length of the stem, the fresh air and root weight which are substantially equal, the roots of the plants inoculated with the isolates RVC13, RCV25, RVC28, RVC38, RVC45, and RVC50 induced a longer root system than the roots of the plants fed with nitrogen. Furthermore, these results have shown that the fresh weight of the roots is more than that of the fresh air weight while the dry weight of the roots is less than the dry air weight except for plants fed in $\mathrm{N}$.

\section{Symbiotic efficiency of rhizobia nodulating bambara groundnut}

The 15 bacteria trapped from 5 different soil samples were able to re-infect and reform functional nodules with plant of $V$. subterranea, variety $\mathrm{Ci} 3$, in various ways. No nodule was formed on the roots of the nitrogenous or non-nitrogenous control plants (Figure 5). These isolates induced a significant number of nodules varying from 18 to 87 nodules/plant, and dry matter varying from 21.67 to $289.33 \mathrm{mg} /$ plant.

Thus, the isolates RVC25, RVC50, and RVC13 were found to be more infectious (Table 2). The indirect measurement of the contributions of nitrogen fixation via the dry matter of shoots and roots, varied considerably between the isolates tested. The shoot dry matter yield of host plant differed significantly among test isolates, with values ranging from $0.51 \mathrm{~g} /$ plant for isolate RCV28 to $1 \mathrm{~g} /$ plant for RVC25.

The shoot dry matter of inoculated plants was higher than the un-inoculated plant ( $\mathrm{N}$-free) and lower than $\mathrm{N}$-fed plants. The relative index (RI) and the relative symbiotic efficiency (REi) evolved in the same direction as the differences observed in the nodulation and the yield in dry weight of the plants, varying from $42 \%$ for the isolates RVC45 and RVC28 to $83 \%$ for RVC25. Based on these criteria, $33 \%$ of the isolates were classified as low $\mathrm{N}_{2}$ fixers $(<50 \% \mathrm{RE})$; while $60 \%$ were nobly effective (50-80\% REi). Only the isolate RVC25 was found to be highly effective (>80\% REi) and identified as having interesting symbiotic characteristics (Table 2).

This study on the genetic and agronomic diversity of symbiotic and non-symbiotic bacteria in Bambara groundnut (Vigna subterranea L. Verdc) was necessary to fill the information gap on the biodiversity of 
rhizobia nodulating this leguminous plant in the African soils, especially in the soil of Côte d'Ivoire.

We investigated the isolation of native rhizobia and proceeded to their genetic and symbiotic efficiency to select the most effective and compatible strains that can be used as biofertilizers.

\section{Isolation of bacteria from bambara groundnut}

A total of 15 bacteria were isolated from the root nodules of the Bambara groundnut inoculated with five soil samples. On solid YEM medium, these bacterial isolates forming gummy colonies with rapid growth were phenotypically diverse in terms of appearance, shape, size and color of the colonies which evoke the rhizobia. It confirms the results reported by Ibny et al., (2019) who revealed that the rhizobial isolates nodulating the Bambara groundnut in Africa showed a great morpho-physiological diversity, which varied from differences in size, shape and texture of the colonies.

Gnangui et al., (2019) also reported that rhizobia isolated from the Bambara groundnut rhizosphere in Côte d'Ivoire had rapid growth. The authors like Grönemeyer et al., (2014), Onyango et al., (2015) and Ngo et al., (2015) previously revealed the nodulation of the Bambara groundnut by both slow- and fastgrowing Bradyrhizobium species.

Table.1 Morpho-agronomic characteristic of inoculated plants

\begin{tabular}{|c|c|c|c|c|c|c|c|}
\hline $\begin{array}{c}\text { Plant } \\
\text { inoculated }\end{array}$ & $\begin{array}{l}\text { Root } \\
\text { color }\end{array}$ & $\begin{array}{l}\text { Leaf } \\
\text { color }\end{array}$ & $\begin{array}{c}\text { Plant } \\
\text { Vitality }\end{array}$ & $\begin{array}{l}\text { Root Length } \\
(\mathrm{cm} / \mathrm{PI})\end{array}$ & $\begin{array}{l}\text { Stem length } \\
(\mathrm{cm} / \mathrm{PI})\end{array}$ & $\begin{array}{c}\text { Aerial fresh } \\
\text { weight (g/PI) }\end{array}$ & $\begin{array}{c}\text { Root fresh } \\
\text { weight }(\mathrm{g} / \mathrm{PI})\end{array}$ \\
\hline N- & W & 3 & + & $18.83 \pm 4.09 \mathrm{c}$ & $14.97 \pm 3.15 \mathrm{a}$ & $2.08 \pm 0.62 b c$ & $3.17 \pm 0.72 b$ \\
\hline RVC6 & LB & 5 & +++ & $24.26 \pm 0.57 \mathrm{bc}$ & $16.80 \pm 1.66 \mathrm{a}$ & $4.00 \pm 0.70 \mathrm{~b}$ & $4.21 \pm 0.30 \mathrm{~b}$ \\
\hline RVC9 & LB & 5 & +++ & $24.36 \pm 0.57 b c$ & $16.90 \pm 1.66 \mathrm{a}$ & $4.11 \pm 0.70 \mathrm{~b}$ & $4.30 \pm 0.30 \mathrm{~b}$ \\
\hline RVC11 & LB & 5 & +++ & $26.87 \pm 2.48 \mathrm{~b}$ & $16.60 \pm 1.56 \mathrm{a}$ & $2.53 \pm 0.68 \mathrm{~b}$ & $3.32 \pm 0.79 \mathrm{~b}$ \\
\hline RVC12 & LB & 4 & ++ & $21.17 \pm 5.49 b c$ & $16.86 \pm 2.00 \mathrm{a}$ & $3.69 \pm 0.90 \mathrm{~b}$ & $4.83 \pm 1.78 \mathrm{~b}$ \\
\hline RVC13 & LB & 5 & +++ & $32.53 \pm 1.88 \mathrm{a}$ & $18.03 \pm 0.59 \mathrm{a}$ & $3.45 \pm 1.46 \mathrm{~b}$ & $5.45 \pm 2.94 \mathrm{ab}$ \\
\hline RVC15 & $\mathrm{W}$ & 4 & ++ & $25.77 \pm 2.63 \mathrm{bc}$ & $16.90 \pm 1.49 \mathrm{a}$ & $2.90 \pm 0.80 \mathrm{~b}$ & $3.69 \pm 0.71 \mathrm{~b}$ \\
\hline RVC23 & LB & 4 & ++ & $26.07 \pm 1.38 \mathrm{bc}$ & $16.37 \pm 1.56 \mathrm{a}$ & $2.58 \pm 0.68 \mathrm{~b}$ & $3.36 \pm 0.79 \mathrm{~b}$ \\
\hline RVC25 & LB & 5 & +++ & $33.03 \pm 1.88 \mathrm{a}$ & $18.53 \pm 0.59 \mathrm{a}$ & $3.95 \pm 1.46 \mathrm{~b}$ & $5.96 \pm 2.92 \mathrm{a}$ \\
\hline RVC28 & LB & 5 & +++ & $34.30 \pm 1.37 \mathrm{a}$ & $19.37 \pm 1.95 \mathrm{a}$ & $2.53 \pm 0.84 \mathrm{~b}$ & $6.09 \pm 0.31 \mathrm{a}$ \\
\hline RVC33 & LB & 5 & +++ & $25.90 \pm 2.92 b c$ & $17.83 \pm 1.86 \mathrm{a}$ & $3.40 \pm 0.43 \mathrm{~b}$ & $4.52 \pm 0.65 \mathrm{~b}$ \\
\hline RVC34 & LB & 5 & +++ & $23.97 \pm 0.57 b c$ & $16.50 \pm 1.66 \mathrm{a}$ & $3.71 \pm 0.70 \mathrm{~b}$ & $3.90 \pm 0.30 \mathrm{~b}$ \\
\hline RVC38 & LB & 5 & +++ & $32.83 \pm 1.88 \mathrm{a}$ & $18.33 \pm 0.59 \mathrm{a}$ & $3.75 \pm 1.46 \mathrm{~b}$ & $5.76 \pm 2.92 \mathrm{ab}$ \\
\hline RVC45 & LB & 5 & +++ & $33.30 \pm 1.30 \mathrm{a}$ & $18.57 \pm 2.13 \mathrm{a}$ & $2.77 \pm 0.72 \mathrm{~b}$ & $5.39 \pm 0.33 \mathrm{ab}$ \\
\hline RVC47 & $\mathrm{W}$ & 4 & ++ & $26.10 \pm 2.92 b c$ & $18.03 \pm 1.85 \mathrm{a}$ & $3.60 \pm 0.44 \mathrm{~b}$ & $4.72 \pm 0.65 \mathrm{~b}$ \\
\hline RVC50 & LB & 5 & +++ & $34.63 \pm 1.11 \mathrm{a}$ & $19.63 \pm 2.09 \mathrm{a}$ & $2.93 \pm 0.83 \mathrm{~b}$ & $6.50 \pm 0.33 \mathrm{a}$ \\
\hline $\mathbf{N}+$ & DB & 5 & +++ & $22.37 \pm 5.06 b c$ & $19.70 \pm 2.90 \mathrm{a}$ & $8.47 \pm 3.06 \mathrm{a}$ & $7.87 \pm 4.88 \mathrm{a}$ \\
\hline
\end{tabular}

Values indicate mean values $( \pm \mathrm{SD})$; different letters indicate significant differences within a row or column at $\mathrm{P}<0.05$ according to the Newman-Keuls test. LB : light brown, DB : Dark brown, W : whitish, 5: dark green, 4 : light green, 3 : greenish, + : weak vitality, ++ : middle vitality, +++ : good vitality 
Table.2 Nodultion and symbiotic effectiveness of Rhizobia nodulating $V$. subterranean

\begin{tabular}{|c|c|c|c|c|c|c|}
\hline $\begin{array}{c}\text { Plant } \\
\text { inoculated }\end{array}$ & $\begin{array}{c}\text { Shoot dry } \\
\text { matter }(\mathrm{g} / \mathrm{Pl})\end{array}$ & $\begin{array}{c}\text { Root dry } \\
\text { matter }(\mathrm{g} / \mathrm{Pl})\end{array}$ & $\begin{array}{l}\text { Nodule } \\
\text { number }\end{array}$ & $\begin{array}{c}\text { Nodule dry } \\
\text { matter (mg/PI) }\end{array}$ & $\begin{array}{l}\text { Relative } \\
\text { index }\end{array}$ & $\begin{array}{c}\text { Symbiotic } \\
\text { efficience } \\
\text { relative } \\
(\%)\end{array}$ \\
\hline $\mathbf{N}-$ & $0.46 \pm 0.10 b c$ & $0.22 \pm 0.03 \mathrm{a}$ & 0 & 0 & 1 & 38 \\
\hline RVC6 & $0.60 \pm 0.32 \mathrm{~b}$ & $0.32 \pm 0.18 \mathrm{a}$ & $20.00 \pm 5.86 \mathrm{f}$ & $25.00 \pm 2.64 \mathrm{i}$ & 1,30 & 50 \\
\hline RVC9 & $0.67 \pm 0.34 b$ & $0.35 \pm 0.15 \mathrm{a}$ & $23.00 \pm 5.86 \mathrm{ef}$ & $40.00 \pm 5.00$ ghi & 1,46 & 55 \\
\hline RVC11 & $0.52 \pm 0.10 \mathrm{bc}$ & $0.27 \pm 0.11 \mathrm{a}$ & $18.00 \pm 6.66 \mathrm{f}$ & $21.67 \pm 4.04 \mathrm{i}$ & 1,13 & 43 \\
\hline RVC12 & $0.71 \pm 0.20 \mathrm{~b}$ & $0.48 \pm 0.27 \mathrm{a}$ & $19.00 \pm 4.16 \mathrm{f}$ & $27.67 \pm 7.09 \mathrm{i}$ & 1,54 & 59 \\
\hline RVC13 & $0.90 \pm 0.56 \mathrm{ab}$ & $0.45 \pm 0.23 \mathrm{a}$ & $67.00 \pm 6.65 \mathrm{~b}$ & $148.33 \pm 12.34 \mathrm{c}$ & 1,96 & 74 \\
\hline RVC15 & $0.59 \pm 0.11 b$ & $0.29 \pm 0.12 \mathrm{a}$ & $27.00 \pm 5.57 \mathrm{ef}$ & $58.00 \pm 7.5 \quad \mathrm{f}$ & 1,28 & 49 \\
\hline RVC23 & $0.61 \pm 0.09 \mathrm{~b}$ & $0.27 \pm 0.10 \mathrm{a}$ & $24.00 \pm 1,50$ ef & $50.67 \pm 2,35 \mathrm{gf}$ & 1,33 & 50 \\
\hline RVC25 & $1,00 \pm 0.56 \mathrm{a}$ & $0.50 \pm 0.27 \mathrm{a}$ & $80.00 \pm 10.02 \mathrm{a}$ & $289.33 \pm 17.92 \mathrm{a}$ & 2,17 & 83 \\
\hline RVC28 & $0.51 \pm 0.13 b c$ & $0.37 \pm 0.16 \mathrm{a}$ & $39.00 \pm 5.51 \mathrm{de}$ & $80.0 \pm 3.00 \quad \mathrm{e}$ & 1,11 & 42 \\
\hline RVC33 & $0.71 \pm 0.13 b$ & $0.46 \pm 0.08 \mathrm{a}$ & $26.00 \pm 6.03 \mathrm{ef}$ & $31.33 \pm 6.03 \mathrm{hi}$ & 1,54 & 59 \\
\hline RVC34 & $0.59 \pm 0.30 \mathrm{~b}$ & $0.34 \pm 0.16 \mathrm{a}$ & $20.00 \pm 5.85 \mathrm{f}$ & $36.00 \pm 7.53 \mathrm{ghi}$ & 1,28 & 49 \\
\hline RVC38 & $0.87 \pm 0.41 \mathrm{ab}$ & $0.41 \pm 0.19 \mathrm{a}$ & $54.00 \pm c ̧ .60 \mathrm{c}$ & $123.33 \pm 11.59 \mathrm{~d}$ & 1,89 & 72 \\
\hline RVC45 & $0.51 \pm 0.13 b c$ & $0.37 \pm 0.17 \mathrm{a}$ & $46.00 \pm 5.51 \mathrm{dc}$ & $116.00 \pm 6.00 \mathrm{~d}$ & 1,11 & 42 \\
\hline RVC47 & $0.63 \pm 0.16 b$ & $0.42 \pm 0.09 \mathrm{a}$ & $32.00 \pm 8.65$ ef & $48.67 \pm 6.50$ gfh & 1,37 & 52 \\
\hline RVC50 & $0.61 \pm 0.13 b$ & $0.44 \pm 0.22 \mathrm{a}$ & $87.00 \pm 9.16 \mathrm{a}$ & $266 \pm 4.00 \quad b$ & 1,33 & 50 \\
\hline $\mathbf{N}+$ & $1.21 \pm 0.49 \mathrm{a}$ & $0.56 \pm 0.29 \mathrm{a}$ & 0 & 0 & 2,63 & 100 \\
\hline
\end{tabular}

Values indicate mean values $( \pm \mathrm{SD})$; different letters indicate significant differences within a row or column at $\mathrm{P}<0.05$ according to the Newman-Keuls test
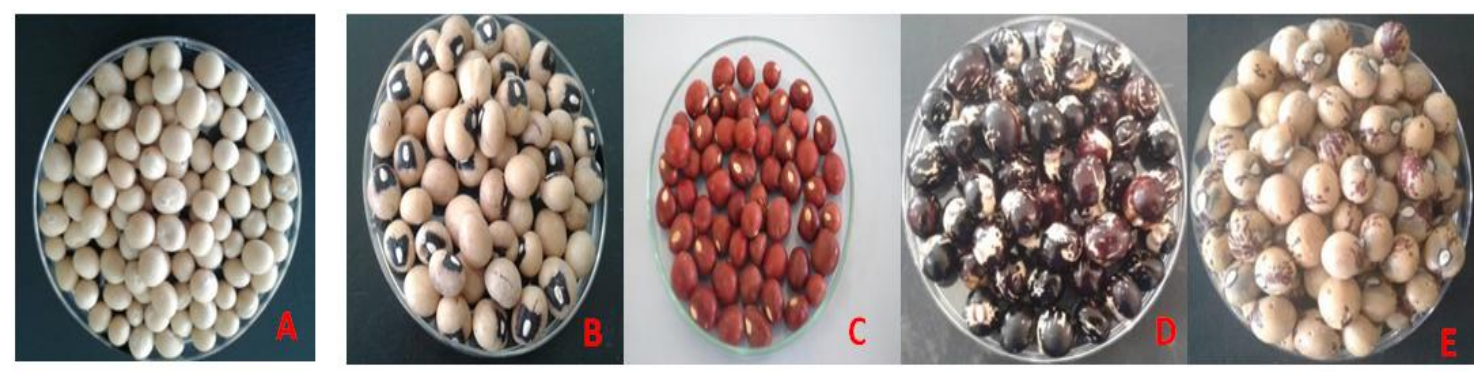

Figure.1 Seeds of different varieties of Vigna subterranea L. Varieties and growing cycles of A (CI1:105J), B (CI6:120J), C (CI5:120J), D (CI3:105J) and E (CI2:120J)
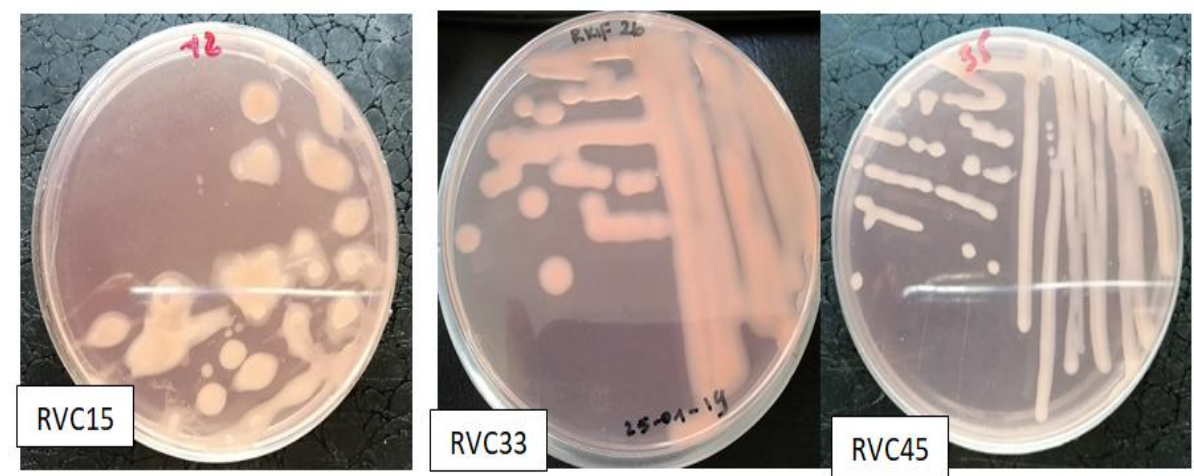

Figure.2 Morphological characteristics of bacteria isolated from $V$. subterranea L. nodules 


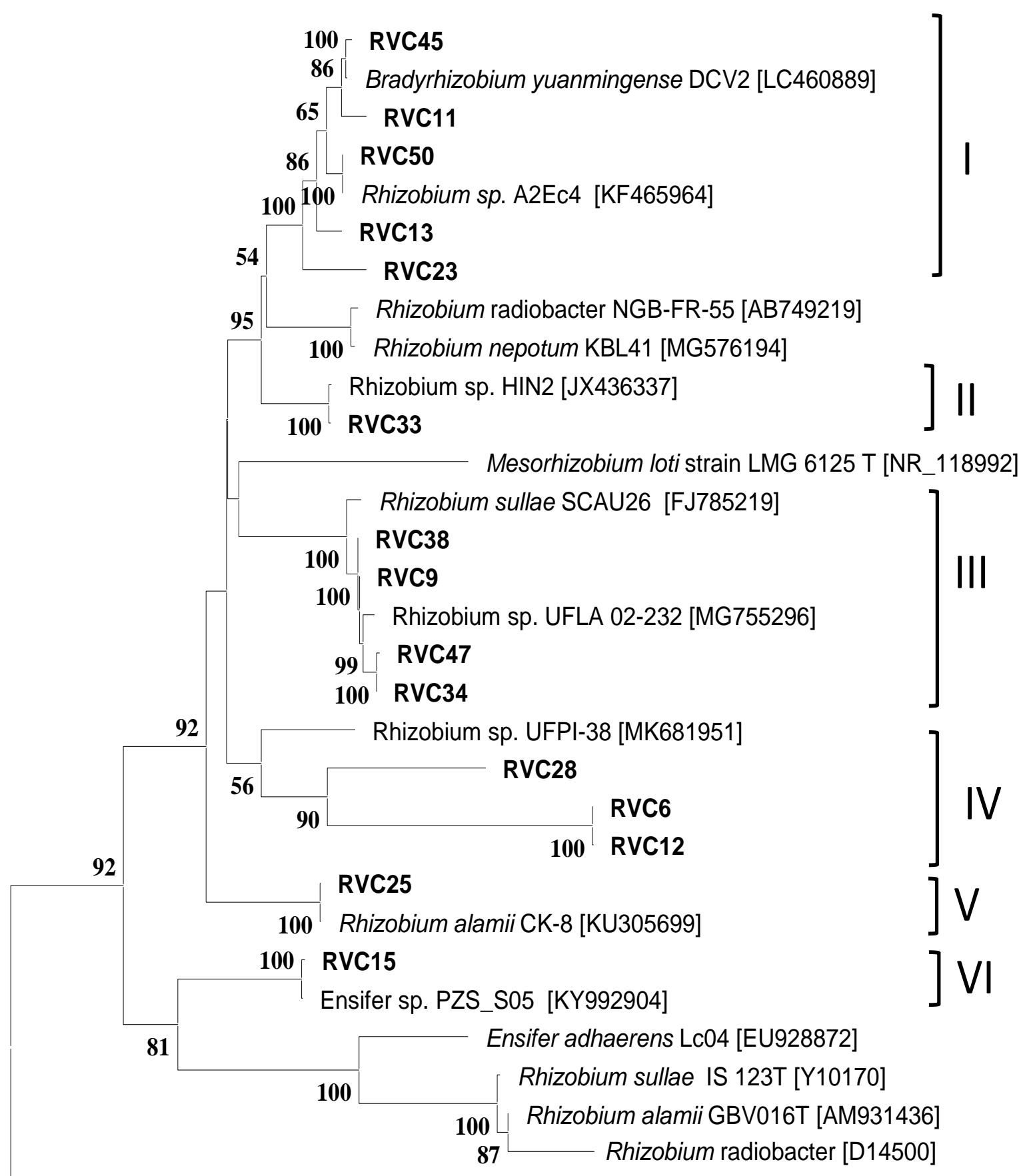

Rhizobium sp. strain 41T [KX884982]

Ensifer adhaerens PZG_S11 [KY660602]

\section{1}

Figure.3 Phylogenetic tree based upon the 16S rRNA sequences obtained by the neighborjoining method. The tree shows the phylogenetic positions of local Bambara groundnut rhizobia isolated from this study (marked in fat) to reference type strains of different rhizobial species.

The tree was tracked according to the boostrap method (100) (100 Rep) 


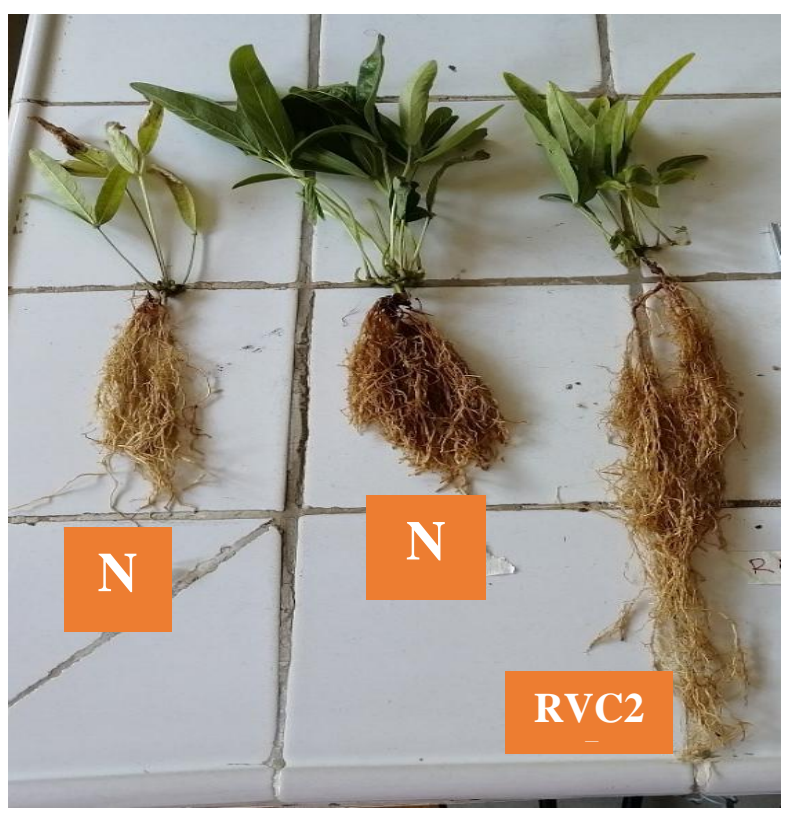

Figure.4 N-free plant (N-), N-fed (N+) and inoculated plant (RVC25) of $V$. subterranea
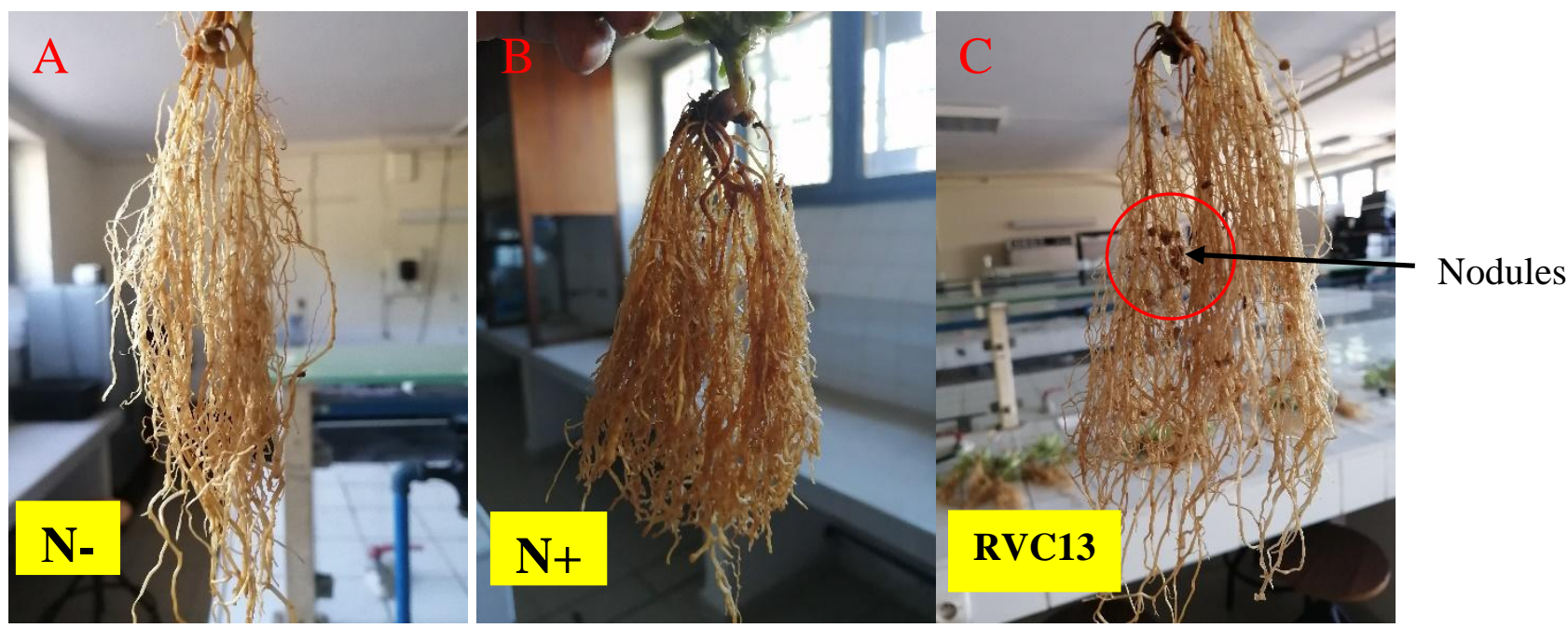

Figure.5 Root systems of N-free plant (A), N-fed plant (B) and inoculated plant (C) of Bambara groundnut

Phylogenetic analysis of the 16S-rRNA gene

The computer analysis of the sequences of the 16S RNA band (1500 Pb) allowed the construction of a phylogenetic tree and the distribution of the 15 bacteria isolated from the nodules of Bambara groundnut into six distinct clusters. These isolates presented a great genetic diversity and grouped respectively with various reference strains, in particular Bradyrhizobium yuanmingense, Rhizobium sp. A2Ec4, Rhizobium sp. HIN2, Rhizobium alamii CK-8, Rhizobium sullae SCAU26, Rhizobium sp. UFLA 02-232, Rhizobium sp. UFPI-38 and Ensifer sp. PZSS05.

Furthermore, Gnangui et al., (2019) isolating rhizobia in the Bambara groundnut rhizosphere in Côte d'Ivoire have shown that these bacteria, based on the sequencing results 
of the 16S RNA gene, phylogenetically were contained 3 main groups, including Rhizobium sp, Rhizobium pusense and an unidentified cluster. However, Ibny et al., (2019) have shown that the Bambara groundnut is generally nodulated in African soils by various species of Bradyrhizobium. Other research has shown that the soil of Côte d'Ivoire contains a genetically polymorphic reservoir of local rhizobia capable of effectively nodulating various leguminous plants including Glycine max L (Amani et al., 2020)

\section{Symbiotic efficiency of rhizobia nodulating bambara groundnut}

A large variability infective capacity of the strains was highlighted in this study. Such variability was related to the genetic diversity of isolates test revealed by16S RNA gene phylogenetic tree.

It confirms the results reported by Guei et al., (2019) and Ibny et al., (2019) which authenticated rhizobiums from Bambara groundnut. This study revealed a large variable infectious capacity of the strains of $V$. subterranea L.

This variability in symbiotic efficiency is linked to the genetic diversity of these strains revealed by the phylogenetic tree of the $16 \mathrm{~S}$ RNA gene. This information is consistent with results reported by Guei et al., (2019) and Ibny et al., (2019) who respectively identified and authenticated the rhizobia associated with Bambara groundnut in Côte d'Ivoire. Indeed, the inoculation of each plant was done with $1 \mathrm{~mL}$ of bacterial broth induced the average number and dry matter of nodule per plant varying respectively from 18 to 87 and 21,67 to $289,33 \mathrm{mg}$. however, Kumari et al., (2010) authenticated the rhizobia isolated from Indigofera species and reported that the average number of nodule varied depending on species. These differences in nodulation and dry weight yield of the plants were accompanied by marked variations in the relative symbiotic efficacy of the isolates tested. Various authors have found strong correlations between aboveground biomass, root biomass and the number and mass of nodules (Fausta, 2013; Ibny et al., 2019).

According to some authors, it does not have, in general, correlations between the symbiotic parameters (Maâtallah et al., 2002; Belay and Fassil, 2010; Guei et al., 2019). For the legume of $V$. subterranea L., this study showed the opposite revealing a correlation between the morpho-agronomic parameters studied and a significant difference between inoculated plants, non-inoculated plants (without N) and plants fed with N. Symbiotic characteristics had a significant contribution to the growth, health and yield of the host plant. In fact, plants inoculated with native bacterial strains exhibiting interesting symbiotic characteristics have generated good morpho-agronomic results in host plants. The soil of the Daloa localities in Côte d'Ivoire is full of rhizobial bacteria capable of infecting and nodulating the legume of Vigna subterranea $\mathrm{L}$. The 15 isolates obtained have variously improved the nodulation and yield of the inoculated plants under glasshouse conditions. Genetic analysis using the $16 \mathrm{~S}$ RNA gene sequencing revealed that these isolates belong to the rhizobia, in particular to Bradyrhizobium yuanmingense, Rhizobium sp. A2Ec4, Rhizobium sp. HIN2, R. alamii CK-8, R. sullae SCAU26, Rhizobium sp. UFLA 02-232, Rhizobium sp.UFPI-38 and Ensifer sp. PZS-S05. In order to conduct a deep assessment of the symbiotic efficacy of the promising isolates, additional studies will be conducted in the field and climate change conditions to confirm the potentials of the rhizobial candidates for mass inoculums production. 


\section{Acknowledgements}

We thank the Ministry of Higher Education and Scientific Research of Côte d'Ivoire for the funding of this research work which is part of the cooperation between our two Laboratories.

\section{References}

Altschul, S. F., Gish, W., Miller W., Myers, E. W. and Lipma, D. J. (1990). Basic local alignment search tool. J. Mol. Biol. 215:403-410. https://doi.org/10.1016/S0022.2836(05) 80360-2.

Amani K., Konate I., N'Gbesso M.F.D.P., Attien Y.P., Fondio L., Filali-Maltouf A. and Sanogo T.A. (2019). Phenotypic and Symbiotic Diversity of Rhizobia Isolated from Root Nodules of Soybean [Glycine $\max$ (L.) Merrill] in Côte d'Ivoire. Int. J. Curr. Microbiol. App. Sci, $\quad 8:$ 766-774. https://doi.org/10.20546/ijcmas.2019.80 3.094

Amani, K., Fondio, L., Konate, I., N'Gbesso, M. F. D. P., Maxwell, B. G. A., Sanogo, T. A. and Filali-Maltouf, A. (2020). Response of Indigenous Rhizobia to the Inoculation of Soybean [Glycine max (L.) Merrill] Varieties Cultivated under Controlled Conditions in Côte d'Ivoire. Adv. in Microb., 10:110-122. https://doi.org/10.4236/aim.2020.10301 0.

Belay, Z. and Fassil, A. (2010). Symbiotic and phenotypic diversity of Zerihun Rhizobium leguminosarum bv.viciae from Northern Gondar, Ethiopia, Afr. J. Biotech. 10:4372-437.

Benhizia Y, Benhizia H, Benguedouar A, Muresu R, Giacomini A and Squartini A (2004). Gamma proteobacteria can nodulate legumes of the genus Hedysarum. Syst Appl Microbiol,
27:462-468.

DOI: $10.1078 / 0723202041438527$

Chen, W. and Tsong-the, K. (1993). A Simple and Rapid Method for the Preparation of Gram-Negative Bacterial Genomic DNA. Nucl. Acids Resear., 21: 2260-2260. https://doi.org/10.1093/nar/21.9.2260.

Chen W.M, Moulin L, Bontemps C, Vandamme P, Béna G. and BoivinMasson C (2003). Legume symbiotic nitrogen fixation by $\beta$ - Proteobacteria is widespread in nature. $J$ Bacteriol, 185:7266-7272.

DOI: $10.1128 / \mathrm{jb} .185 .24 .7266-$ 7272.2003

Cheriet, D. (2016). Etude des bactéries symbiotiques de la luzerne (Medicago ciliaris L.) fixatrices d'Azote. Thèse de Doctorat, Université Badji Mokhtar, Annaba, p 38.

Chibeba, A. M., Kyei-Boahen, S., de Fátima, G. M., Nogueira M. A. and Hungria, M. (2018). Feasibility of transference of inoculation related technologies: A case study of evaluation of soybean rhizobial strains under the agro-climatic conditions of Brazil and Mozambique. Agric. Ecosyst. Environ. 261, 230-240. https://doi.org/10.1016/j.agee.2017.06.0 37.

Dixon R.O.D. and Wheeler C.T. (1986). Nitrogen fixation in plants. Blackie, Glasgow, United Kingdom.

Fausta, K. (2013). Caractérisation de l'efficacité symbiotique de lignées africaines de soya à haute promiscuité. Mémoire de Maîtrise en biologie végétale, Université Laval, P 52-54. http://hdl.handle.net/20.500.11794/2434 3.

Garrity G.M, Bell JA, and Lilburn T.G (2003). Taxonomic outline of Prokaryotes. In: Garrity GM (ed) Bergey's manual of systematic bacteriology. 2nd edn. Springer, New 
York

Gnangui, E. L. S, Kouadjo, Z. G. C., and Zeze, A. (2019). First report of Rhizobium pusense within Voandzou (Vigna subterranea (L.) Verdc.) rhizosphere in Côte d'Ivoire, Microb. Nat. 1:55-65. https://doi.org/10.26167/CZTB-1P42.

Graham, P. H. (2008). Ecology of the rootnodule bacteria of legumes. In Nitrogen-fixing leguminous symbioses. 23-58. DOI: 10.1007/978-1-4020-35487 9.

Grönemeyer, J. L., Kulkarni, A., Berkelmann, D., Hurek, T. and Reinhold-Hurek, B. (2014). Identification and characterization of rhizobia indigenous to the Okavango region in Sub-Saharan Africa. Appl. Environ. Microbiol. 80:7244-7257. https:// doi:10.1128/AEM.02417-14.

Guei, N. K. R., Konate, I., Bakayoko, S., Ouattara, A., Amani, K., Tidou, A.S. and Filali-Maltouf, A. (2019). Nodulation and agronomic performance of indigenous rhizobia isolated from Bambara grounnut (Vigna subterranea L.) nodules in Daloa, Côte d'Ivoire, Inter. J. Resear. Stud. Microb. Biotech., 2:13-18.

http://dx.doi.org/10.20431/2454-

9428.0502004.

Hassen A.I., Bopape F.L. and Trytsman M. (2014). Nodulation Study and Characterization of Rhizobial Microsymbionts of Forage and Pasture Legumes in South Africa. World Journal of Agricultural Research, 3:93100. http://pubs.sciepub.com/wjar/2/3/2

Ibny, I. Y. F., Jaiswa, K. S., Mohammed, M. and Dakora, D. F. (2019). Symbiotic effectiveness and ecologically adaptive traits of native rhizobial symbionts of Bambara groundnut (Vigna subterranea L. Verdc.) in Africa and their relationship with phylogeny, Sci. Rep.,
9:12666.

https://doi.org/10.1038/s41598-01948944

Kumari, B. S., Ram, M. R. and Mallaiah, K. V. (2010). Studies on nodulation, biochemical analysis and protein profiles of Rhizobium isolated from Indigofera species , Mal. J. Microbiol, $6: 133-139$.

Maâtallah, J, Berraho, E. B, Munoz, S, Sanjuan, J. and Lluch, C. (2002). Phenotypic characterization of rhizobia isolated from chickpea (Cicer arietinum L.) growing in Moroccan soils. Agronomie. $\quad 22, \quad 321-329$. https://doi.org/10.1046/j.13652672.2002.01718.x.

Ngo, N. L., Ngo, B. M., Fankem, H., Adamou, S., Kamguia, K., Ngakou, A., Nwaga, D., and Etoa, F. X. (2015). Isolation and screening of indigenous bambara groundnut (Vigna subterranea) nodulating bacteria for their tolerance to some environmental stresses. Am. J. Microbiol. Res. 3 :65-75. DOI:10.12691/ajmr-3-2-5.

Normand, P., Ponsonnet, C., Nesme, X., Neyra, M., and Simmonet, P. (1996). ITS analysis of prokaryotes. In: molecular microbiology ecology manual. Dordrecht. The Netherlands: Kluw. Acad. Publis., 1-12.

Onyango, B., Anyango B., Nyunja, R., Koech, P. K., Skilton, R. A. and Stomeo, F. (2015). Morphological, genetic and symbiotic characterization of root nodule bacteria isolated from Bambara groundnuts (Vigna subterranea L. Verdc) from soils of Lake Victoria basin, western Kenya. $J$. App. Biotech; 3:001-010. https://doi.org/10.7324/JABB.2015.310 1.

R Core Team (2018). R: A Language and Environment for Statistical Computing. R Foundation for Statistical Computing, 
Vienna, Austria. https://www.Rproject.org/.

Ren D.W., Wang E.T., Chen W.F., Sui X.H., Zhang X.X., Liu H.C. and Chen W.X. (2011). Rhizobium herbae sp. nov. and Rhizobium giardinii-related bacteria, minor microsymbionts of various wild legumes in China. Inter. J. Syst. Evol. Microb., 61:1912-1920. DOI 10.1099/ijs.0.024943-0

Rincón A., Arenal F., González I., Manrique E., Lucas M.M. and Pueyo J.J. (2008). Diversity of Rhizobial Bacteria Isolated from Nodules of the Gypsophyte Ononis tridentata L. Growing in Spanish Soils. Microb Ecol. 56:223233. DOI: $10.1007 / \mathrm{s} 00248-007-9339-6$

Sayeda A., Gamil A., Mohammed F., Mahmoud T.E.L., Mohammed M. and Nabil N. (2005). Production of rhizobia biofertilizers using baker's yeast effluent and their application to Leucaena leucocephala. Archi. Agron. Soil Sci. 51: 605-617.

DOI: $10.1080 / 03650340500273732$

Sessitsch A., Howieson J.G., Perret X., Antoun H. and MartínezRomero E. (2002). Advances in Rhizobium Research. Critical Reviews in Plant Sciences, 21(4):323-378.

Sylla S.N., Samba R.T., Neyra M., Ndoye I., Giraud E., Willems A., Lajudie P.D, and Dreyfus B. (2002). Phenotypic and
Genotypic Diversity of Rhizobia Nodulating Pterocarpus erinaceus and $P$. lucens in Senegal. System. Appl. Microbiol. 25:572-583. http://www.urbanfischer.de/journals/sa $\mathrm{m}$

Tamura, K., Stecher, G., Peterson, D., Filipski, A. and Kumar, S. (2013). MEGA6: molecular evolutionary genetics analysis version 6.0. Mol Biol Evol. 30:2725-2729. https:// dx.doi.org/10.1093/molbev/mst/197.

Torres-Júnior C.V., Leite J., Santos C.E.D.R.E.S., Fernandes-Júnior P.I., Zilli J.É., Rumjanek N.G. and Xavier G.R. (2014). Diversity and symbiotic performance of peanut rhizobia from Southeast region of Brazil. African Journal of Microbiology Research, 8:566-577.

Vincent, J. M. (1970). A Manual for the Practical Study of Root Nodule Bacteria. I.B.P. Handbook no.Oxford: Blackwell. https://doi.org/10.1002/jobm.19720120 524.

Weisburg, W. G., Barns, S. M., Pelletier, D. A. and Lane, D. J. (1991). 16S Ribosomal DNA Amplification for Phylogenetic Study, J. Bacteriol., 173:697-703 https://doi.org/ 10.1128/jb.173.2.697703.199 .

\section{How to cite this article:}

Guei Nassé Kaéda Raissa, Konate Ibrahim, Taha Kaoutar, Bamba Issouf, Beugre Grah Avit Maxwell, Akaffou Doffou Sélastique and Filali-Maltouf Abdelkarim. 2020. Molecular and Symbiotic Efficiency Characterization of Rhizobia Nodulating Bambara Groundnut (Vigna subterranea L.) from Agricultural Soils of Daloa Localities in Côte D'ivoire. Int.J.Curr.Microbiol.App.Sci. 9(07): 507-519. doi: https://doi.org/10.20546/ijcmas.2020.907.056 